\title{
Increasing the shelf life of post-harvest table grapes (Vitis vinifera $c v$. Thompson Seedless) using different packaging material with copper nanoparticles to change the atmosphere
}

\author{
Nelson E. Loyola López, Marcos R. Carrasco Benavides, Pablo H. Duarte \\ Duarte, and Mariela A. Arriola Herrera. \\ Universidad Católica del Maule, Facultad de Agricultura y Ciencias Forestales, Departamento de Ciencias \\ de la Agricultura. 684 Carmen, Curicó, Chile.
}

\begin{abstract}
N.E. Loyola López, M.R. Carrasco Benavides, P.H. Duarte Duarte, and M.A. Arriola Herrera. 2017. To increase shelf life table grapes using different packaging material with copper and nano-particles to change atmosphere in post-harvest table grapes. (Vitis vinífera) cv. Thompson Seedless. Cien. Inv. Agr. 44(1): 54-63. An effective way to control post-harvest rotting of table grapes is the use of sulfur dioxide $\left(\mathrm{SO}_{2}\right)$. However, under certain conditions, the use of $\mathrm{SO}_{2}$ can cause significant loss, mainly associated with bleaching of the berries. Therefore, it is believed that the use of bags with and without copper nanoparticles that modify the atmosphere will allow for the control of Botrytis cinerea as well as the ability to dispense with the use of sulfur dioxide generation. The objective of this test is to evaluate the use of bags with and without copper nanoparticles that modify atmosphere and to evaluate their ability to control post-harvest $B$. cinerea, as well as their effect on the conservation of physical and chemical characteristics of table grapes. The results indicate that the use of air bags with or without copper nanoparticles that modify the atmosphere and do not require sulfur dioxide generation were able to control $B$. cinerea post-harvest and preserve the physical and chemical parameters of grape table cv. 'Thompson seedless'. Significant differences were seen in parameters such as whitening, dehydration and incidence of stalk rot. A group of panelists could not distinguish differences in the sensory attributes and acceptability of the grapes regardless of treatment.
\end{abstract}

Keywords: Modification of atmosphere, rotting, sulfur dioxide $\left(\mathrm{SO}_{2}\right)$.

\section{Introduction}

World production of grapes, according to the International Wine Organization (IWO), reached 69.2 million tons in 2011. Furthermore, despite the decrease in the global vineyard area, grape

Received July 13, 2016. Accepted March 17, 2017.

Corresponding author: nloyola@ucm.cl; nelsonloyola@hotmail.com production has followed an upward trend, and growth has been based primarily on the continued increase of the production of table grapes, which experienced an increase from 17.5 million tons in 2003 to 22.3 million tons in 2011 (Bravo, 2013).

The Thompson seedless grape variety was the most exported variety in the 2013 season. It recovered from a steady decline in recent years, registering 
a growth of $9.9 \%$ and increasing its participation from 22.7 to $24.5 \%$ (Bravo, 2013).

The Thompson seedless grape variety has green fruit, ripens midseason, requires gibberellic acid for the elongation of the spine, the thinning of flowers and berry enlargement and has indispensable conditions for export. This variety is also used in the production of canned raisins and wine (Valenzuela and Lobato, 2001). It has good storage requirements, neither being affected by most stalk characteristics nor shattering more than the maximum allowed within a reasonable period of cold storage for 45-60 days (Muñoz and Lobato, 2000).

Bruises, dehydration, and rotting are the greatest dangers to table grapes after harvest. The most important cause of loss is associated with rotting, mainly due to the gray mold Botrytis cinerea (Snowdon, 1990).

Sulfur dioxide $\left(\mathrm{SO}_{2}\right)$ is an effective fungicidal agent, applied by spraying through $\mathrm{SO}_{2}$ package generators (Snowdon, 1990). However, under certain conditions, the use of $\mathrm{SO}_{2}$ can cause significant losses due to grapes damage, identified by small amounts of staining in each of the berries and in some severe cases, it can even whiten the whole berry. Furthermore, $\mathrm{SO}_{2}$ has harmful effects on the grape and its health, altering its metabolism by oxidative stress (Giraud et al., 2012) Thus, the metabolic waste is analyzed in grape boxes that show the biggest penetration, which for safety should not exceed $3.0 \mathrm{ppm}$, accounting for analytical variability. However, the maximum tolerated waste is $10 \mathrm{ppm}(\mathrm{Gil}, 2012)$. An alternative method is the use of modified atmosphere bags, showing characteristics of variable gas permeability to allow for changes in gas concentrations, including lowering $\mathrm{O}_{2}$ and increasing $\mathrm{CO}_{2}$ concentrations (Fick's law) and relative humidity to regulate metabolism and extend the life of the fruits (Kader et al., 1989). To answer the abovementioned problem, a hypothesis is stated: using bags with and without copper nanoparticles that modify atmosphere would allow for control of Botrytis cinerea and would not require the use of sulfur dioxide generation.

Nanoparticle modified atmosphere bags have an electrochemical property that allows copper to alter proteins within the microbial cell, inhibiting or even eliminating its metabolic functions in many types of microorganisms such as bacteria, viruses, parasites and fungi. The general objectives were to evaluate the use of bags with and without copper nanoparticles to change the atmosphere for post-harvest table grapes, to determine the impact of using these bags on the control of post-harvest $B$. cinerea and to evaluate their effect on the conservation of physical and chemical properties of table grapes.

The specific objectives defined were to evaluate the various attributes of quality and condition of the fruit, such as soluble solids, weight loss, dehydration of the stalk (visual), titratable acidity, whitening and shattering; evaluate gas content, $\mathrm{O}_{2}, \mathrm{CO}_{2}$ and $\mathrm{SO}_{2}$ in bags with and without copper nanoparticles throughout storage; assess the severity and incidence of damage caused by post-harvest pathogens; and perform a sensory evaluation to identify sensory attributes and measure levels of acceptability.

\section{Materials and methods}

The species used was the Thompson seedless grapes variety from an orchard located in the region of O'Higgins, Colchagua Province, Placilla Commune, lat 34 $34^{\prime} 34.9^{\prime \prime} \mathrm{S}$ and long 70 58'24.9' $\mathrm{O}$, where the climate is characterized by temperatures ranging on average between a maximum of $28.9^{\circ} \mathrm{C}$ in January and a low of $4.2^{\circ} \mathrm{C}$ in July (Santibañez and Uribe, 1993). This region has a floor rate corresponding to a Talcarehue salty clay loam (CIREN CORFO, 1997).

In packaging, the following components were used: a Paclife modified atmosphere bag without 
copper nanoparticles, composed mainly of 3 layers of polyethylene (Paclife Manufacturer); a Lifespan modified atmosphere bag without copper nanoparticles, composed mainly of nylon 6; an exchange perforated bag with $0.9 \%$ copper nanoparticles, composed of polyethylene; and an atmosphere bag modified with nanoparticles of copper, composed of 3 layers of polyethylene.

Once the fruit was harvested with an index of maturity based on Brix greater than 17 as measured by a refractometer, it was sprayed with 200 ppm of sulfur dioxide for $30 \mathrm{~min}$. Then, it was transferred from the orchard to the packing area to be packed in the different types of bags before being transported to the freezers in FRUSAN enterprise. Cold rooms had a volume of $1750 \mathrm{~m}^{3}$ and a capacity of 330 pallets with a temperature of $0{ }^{\circ} \mathrm{C}$ and a relative humidity of $90 \%$. After the fruit arrived in the cold rooms for precooling, it was removed when the pulp temperature was between -0.5 and $0.5^{\circ} \mathrm{C}$. After being pre-cooled, the fruit was stored at $0{ }^{\circ} \mathrm{C}$ and relative humidity above $85 \%$ for evaluation $50 \mathrm{~d}$ later, simulating the destiny to Asia (data not shown).

The test consisted of using bags with and without copper nanoparticles, in which the control treatment $\left(\mathrm{T}_{0}\right)$, termed "generic packaging," was absent from these bags as mentioned above. The test was structured as follows:

The corrugated cardboard box provides cushioning for the shock produced during packing and transport of the grape. The $95 \times 65$ A / D shirttype perforated USDA transparent bags with $0.9 \%$ ventilation were used. A roll of white wrapping paper $(45 \times 50,21 \mathrm{~g})$ was added to each side of each case. The bottom contained a $30 \times 46 \mathrm{~cm}$ perforated plastic generator, corresponding to a $3 \mathrm{~g}$ slow phase source of sulfur dioxide with sodium metabisulfite and a $36 \times 47$ absorbing single-laminar USDA micro perforated pad. This generator absorbs excess moisture in the box. A grape carry bag (PLU $4022 \mathrm{w} /$ zipper) contained the clusters; another USDA absorbing single- laminar pad $36 \times 47$ micro was placed to absorb an excess of humidity in the box. A generator (USA $33 \times 466+1$ blue) was placed on top of the box, corresponding to a sulfur dioxide generator of a $6 \mathrm{~g}$ slow release and a quick release of 1 $\mathrm{g}$ of sodium metabisulfite. Finally, a shirt-type adhesive closure printed $4 \mathrm{~cm}$ in diameter was used to close the bag, like a shirt, culminating in the covering of the box of table grapes for export.

$\mathrm{O}_{2}, \mathrm{CO}_{2}$ and $\mathrm{SO}_{2}$, gases were measured every day for one week using the following equipment: Check Point GDP equipment, Dansersor A / S Model (Dansersor Manufacturer) was used to measure $\mathrm{CO}_{2}$ and $\mathrm{O}_{2}$ and MultiRAE Lite equipment, Lite Model PGM-6208 (RAE SYSTEMS manufacturer) was used to measure $\mathrm{SO}_{2}$. After the initial week, the gases were measured once a week until the boxes were opened. The measurement of the dehydration of the stalk was carried out visually, using the following scale (Lavanderos, 1998):

0 : Absence of dehydration. Rachis and turgid green stalk.

1: Mild dehydration. Brown rachis and green stalks.

2: Moderate dehydration. Brown stalk and rachis

3: Severe dehydration. Rachis with brown stalk and with a loss of turgor

To determine the weight of each experimental unit, which corresponds to a box of $8.2 \mathrm{~kg}$ with 14 clusters of $586 \mathrm{~g}$ each, we used a $5000 \mathrm{~g}$ digital scale, Model SF-400, Generic Mark. Each batch of treated grapes was weighed at the time of packaging and again after $50 \mathrm{~d}$ of storage.

To measure the titratable acidity, $10 \mathrm{~mL}$ of homogenized juice was taken from each treatment group and placed in a flask, and 3 to 4 drops of phenolphthalein were added and then titrated with sodium hydroxide $(\mathrm{NaOH})$ until the juice changed color. 
Presence of soluble solids was determined with an ATAGO ATC-1 thermocompensated refractometer, ranging from 0 to $30^{\circ} \mathrm{Brix}$ following the AOAC method 932.12 (A.O.A.C 1990).

A sensory evaluation was performed seven days following the end of the 50 -d storage at $0^{\circ} \mathrm{C}$ which was maintained for $7 \mathrm{~d}$ at $5{ }^{\circ} \mathrm{C}$, simulating the conditions during sale to consumers. Evaluation primers were used for the sensory analysis of the fruits, which allowed the determination of the organoleptic characteristics among treatments. Twenty-nine trained evaluators performed an acceptance test of the product. This analysis was carried out in the laboratories of the Catholic University of Maule, Campus Our Lady of Carmen, located in the commune of Curicó, Maule. For this analysis, each person received numbered samples and two types of primers: unstructured and structured. The first primer was to assess the degree of perceived attributes such as color, texture, flavor and aroma and the second primer was to measure acceptability of fruits (adapted from Meilgaard et al., 1999).

The study design was completely randomized, where the experimental unit was fruit packed in an $8.2 \mathrm{~kg}$ box, of which an average amounted approximately 14 clusters. Nine treatments with 4 replications were considered and subjected to repeated ANOVA on each container. The results obtained were subjected to statistical analysis using the Tukey test $(\mathrm{P}<0.05)$ for all parameters evaluated. Excel and SPSS 15.0 were used for data storage and for the collection of statistical values.

\section{Results}

The soluble solids measured in table grapes cv. Thompson seedless showed no significant differences between treatments $(\mathrm{P} \leq 0.262)$ after 50 $\mathrm{d}$ of being stored (Figure 1).

Because grape berries are non-climacteric, they have no breathing increase during the ripening process, meaning the fruit does not ripe and sugar content does not change once they have been harvested (Retamales and Defilippi, 2000). Non-climacteric fruits develop slowly and mature over a long period of time, with ever-decreasing breathing at a low intensity. Maturity of the fruit at harvest is equivalent to that of the fruit when it reaches the consumer (Gil, 2012), explaining the lack of significant changes in relation to any of the treatments.

The weight measurements of table grapes cv. Thompson seedless did not differ significantly $(\mathrm{P} \leq 0.102)$ after $50 \mathrm{~d}$ of being stored under either treatment (Figure 2).

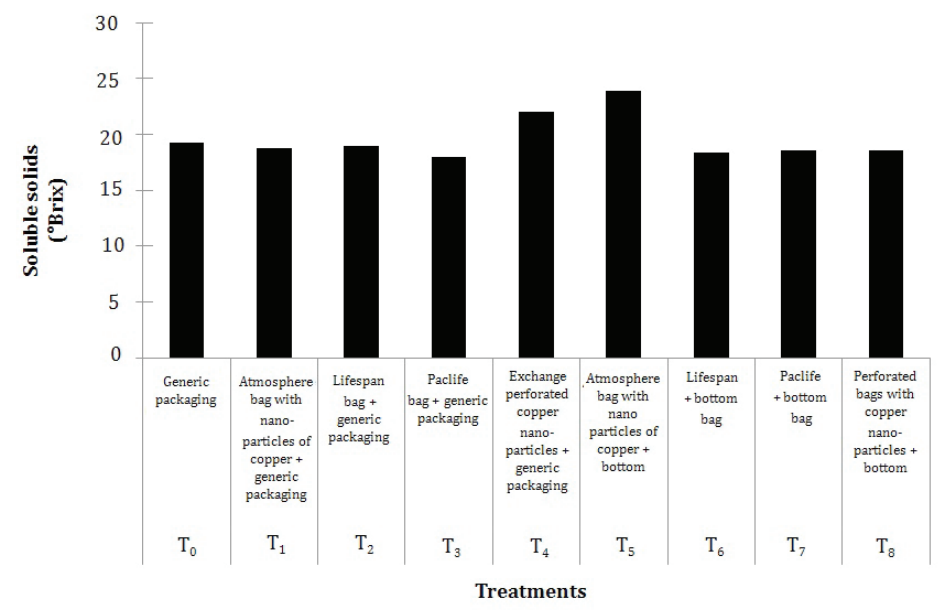

Figure 1. Comparison of average soluble solids between treatments measured after $50 \mathrm{~d}$ of storage. 


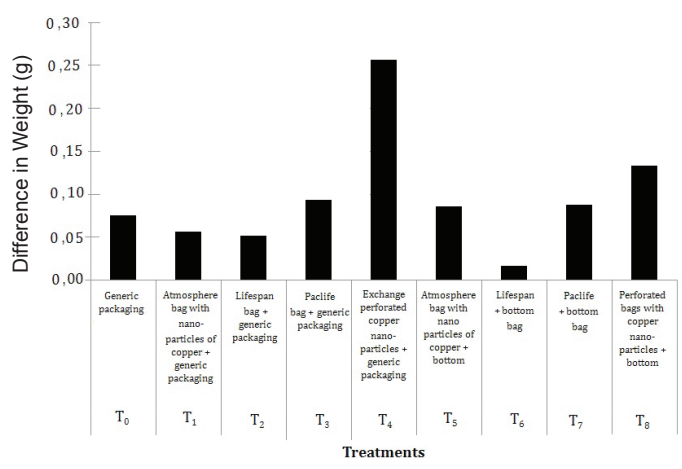

Figure 2. Comparison of average weight differences between treatments measured after $50 \mathrm{~d}$ of being stored.

The absence of significant differences among treatments could be due to storage conditions, which were enough to maintain grapes independently of their packaging material. Kader (2004), indicates that the ideal conditions for grape storage are a temperature range between -0.5 at $0{ }^{\circ} \mathrm{C}$ and a relative humidity of 90 to $95 \%$. This indicates that regardless of the packaging materials used in this test, there was no salable weight loss for any of the treatments.

The level of dehydration measured in table grapes $\mathrm{cv}$. Thompson seedless, showed no significant differences $(\mathrm{P} \leq 0.000)$ between treatments after $50 \mathrm{~d}$ of storage (Figure 3).

Figure 3 shows that the treatments in which there were no significant differences between them are those that did not have the Lifespan bag $\left(\mathrm{T}_{1}, \mathrm{~T}_{3}, \mathrm{~T}_{4}\right.$, $\mathrm{T}_{5}, \mathrm{~T}_{7}$ and $\mathrm{T}_{8}$ ), with the $\mathrm{T}_{6}$ treatment comparable

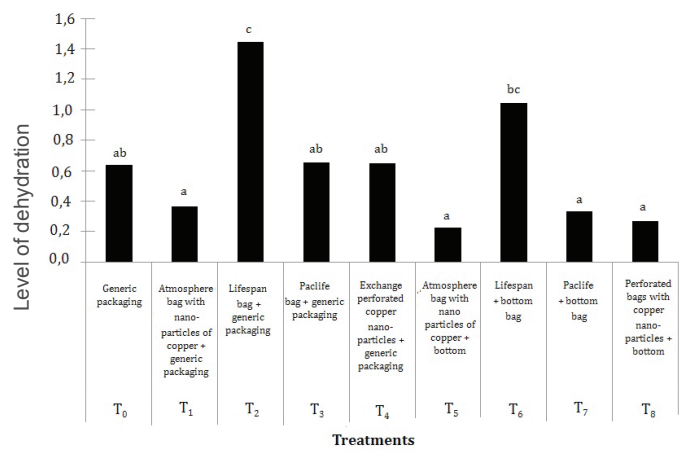

Figure 3. Comparison of average levels of dehydration in different treatments measured after $50 \mathrm{~d}$ of storage. Different letters indicate statistically significant differences. to $\mathrm{T}_{2}$ in the level of dehydration. Consequently, treatments showing the highest dehydration were the treatments that had Lifespan bags $\left(\mathrm{T}_{2}\right.$ and $\mathrm{T}_{3}$ ), with a of dehydration level of 1 , which is a mild dehydration characterized by brown and green stalks in the spine. This could be due to the composition of the LifeSpan bags since they are manufactured with a higher proportion of polypropylene, which makes them more permeable to water vapor, unlike Paclife bags that are less permeability to water vapor.

Regarding treatments with and without perforated bags with copper nanoparticles, a sulfur dioxide generator would preserve the level of dehydration of the spine, favoring the maintenance of a good appearance of the stalk for its antioxidant effect, thus preventing the waste of its natural color (Harvey and Uota, 1978).

Titratable acidity measured in table grape cv. Thompson seedless showed no significant differences between treatments $(\mathrm{P} \leq 0.770)$ after 50 $\mathrm{d}$ of being stored (Figure 4).

Acid concentration generally decreases during maturation of most fruit as a result of breathing carbohidrates not only substrates but also structures (Gil, 2012). However, there were no significant differences among treatments, indicating that the treatments applied in this test did not affect the natural decline of the titratable acidity of the fruit.

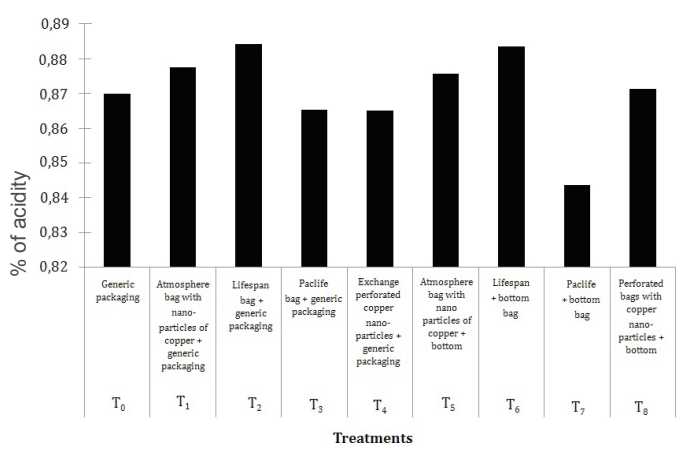

Figure 4. Comparison of average \% acidity between treatments, measured after $50 \mathrm{~d}$ of storage. Different letters indicate statistically significant differences. 
We observed no significant differences in the whitening of table grapes cv. Thompson seedless showed no significant differences between groups $(\mathrm{P}<0.000)$ after $50 \mathrm{~d}$ of storage (data not shown).

The treatment with the fewest bleached berries was $\mathrm{T}_{8}$, showing no significant differences with fruit in treatments $\mathrm{T}_{2}, \mathrm{~T}_{4}, \mathrm{~T}_{5}, \mathrm{~T}_{6}$ and $\mathrm{T}_{7}$ (data not shown). Grapes from treatments $\mathrm{T}_{0}, \mathrm{~T}_{1}$ and $\mathrm{T}_{3}$ had the highest number of berries with whitening. In treatments with a sulfur dioxide generator, a clear difference was observed in fruits which had this generator $\left(\mathrm{T}_{0}, \mathrm{~T}_{1}, \mathrm{~T}_{2}, \mathrm{~T}_{3}\right.$ and $\left.\mathrm{T}_{4}\right)$ and those without it $\left(\mathrm{T}_{5}, \mathrm{~T}_{6}, \mathrm{~T}_{7}\right.$ and $\left.\mathrm{T}_{8}\right)$. The fruit from the second group presented with the lowest levels of bleaching, with the exception that fruits from $\mathrm{T}_{7}$, which showed levels of bleaching similar to those of the berries with a sulfur dioxide generator. This could be because the Paclife bag is less permeable due to its 3 layers of polyethylene, which may generate an excess of sulfur dioxide inside the bag.

No significant differences in the shelling measured in table grapes $\mathrm{cv}$. Thompson seedless were seen $(\mathrm{P} \leq 0.353)$ for any treatment after $50 \mathrm{~d}$ of storage (data not shown). Shelling is mainly associated with mismanagement of the fruit during harvesting and packing in the field. However, the shattering of berries also occurs during handling and packaging continues until the final sale of the fruit Crisosto et al., (2013); Calvo (1994), also notes that excessive handling during harvesting, packing and moving is largely responsible for shelling, in addition to other factors that negatively influence and increase shelling, such as hot/dry climates, deficiency of soil moisture during the ripening period and late harvest.

Significant differences in the number of berries with rot measured on grapes cv. Thompson seedless $(\mathrm{P} \leq 0.001)$ between treatments (Figure 5) were obtained after $50 \mathrm{~d}$ of storage.

In Figure 5, it is shown that fruit with no rot incidence were the ones in groups $\mathrm{T}_{1}, \mathrm{~T}_{2}$ and $\mathrm{T}_{6}$.
These conditions are observed to be ideal for this parameter. However, the treatments $\mathrm{T}_{0}, \mathrm{~T}_{3}, \mathrm{~T}_{4}$, $\mathrm{T}_{5}$ and $\mathrm{T}_{7}$ displayed no significant differences. Moreover, fruit with treatments $T_{1}, T_{2}$ and $T_{6}$ showed significant differences to those in treatment $\mathrm{T}_{8}$, which was the treatment with the highest incidence of rotting berries. The reason $T_{8}$ was the treatment that showed the highest incidence of rot is because copper is first absorbed on the surface of the spore and after being in contact with them for long periods, it then penetrates it. If the spores are exposed to copper for short periods, the effect of copper is fungicidal, i.e., if the spores are washed free of copper on their surface, they germinate without difficulty (Melendez, 1974). This indicates that in grapes, not having been in direct contact with the copper nanoparticle bag could prevent the fungicidal effect.

In Figure 5, two well-marked groups are formed, one with the sulfur dioxide generator and one without. The first group had the lowest rot levels, indicating that treatment with the atmosphere bag with nanoparticles of copper + generic packaging $\left(T_{1}\right)$ will have the lowest levels of rot, despite copper nanoparticles not contacting the fruit. Furthermore, LifeSpan + bottom treatment group $\left(\mathrm{T}_{6}\right)$ had low levels of rot without the presence of a sulfur dioxide generator, indicating the LifeSpan bag provided the closest ranges to the ideal levels of $\mathrm{O}_{2}$ (data not show) and $\mathrm{CO}_{2}$ (Figure 6). Oxygen measured in table grapes cv. Thompson seedless

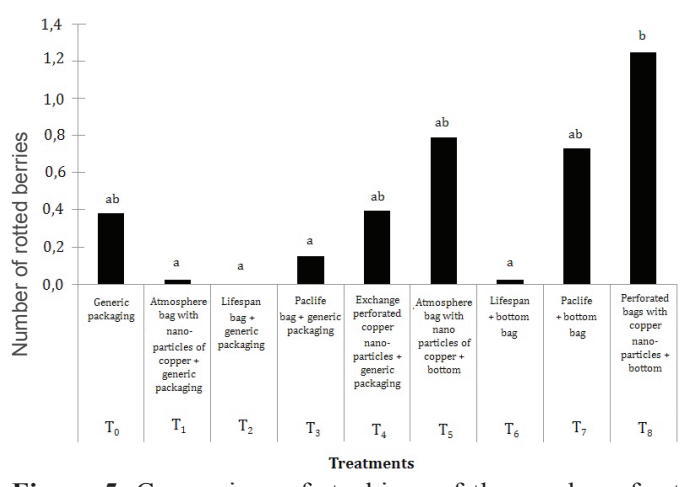

Figure 5. Comparison of stockings of the number of rot berries with different treatments measured after $50 \mathrm{~d}$ of storage. Different letters indicate statistically significant differences. 
showed significant differences $(\mathrm{P} \leq 0.000)$ between treatments after $50 \mathrm{~d}$ of storage, suggesting that the treatment provided closer levels to those with the LifeSpan + generic packaging $\left(\mathrm{T}_{2}\right)$, which showed no significant differences with Paclife Bag + generic packaging $\left(\mathrm{T}_{3}\right)$ and Lifespan Bag + Bottom $\left(\mathrm{T}_{6}\right)$. Furthermore, $\mathrm{T}_{2}$ had significant differences compared with the other treatments. This is associated with $\mathrm{O}_{2}$ permeability of the bags, as the Lifespan bags are formed with Polypropylene, which is less permeable to $\mathrm{O}_{2}$ than the Paclife bags, which are made by a lowdensity polyethylene. Thus, treatments that had a Lifespan bag showed lower levels of $\mathrm{O}_{2}$ than the rest of the bags.

Carbon dioxide measured in table grapes cv. Thompson seedless showed significant differences $(\mathrm{P} \leq 0.000)$ between the treatments after $50 \mathrm{~d}$ of storage (Figure 6).

Figure 6 shows that the treatment resulting in levels closest to those mentioned above by Kader (2004) was the LifeSpan + generic packaging $\left(\mathrm{T}_{2}\right)$. This treatment showed significant differences from all treatments except for the Lifespan treatment + Bottom Bag $\left(\mathrm{T}_{6}\right)$. This is associated with the permeability of the bags to $\mathrm{CO}_{2}$ and the process of breathing in fruit. A Lifespan bag is made mainly of polypropylene which is less permeable to $\mathrm{CO}_{2}$ than a Paclife bag formed by low density polyethylene, resulting in higher levels of $\mathrm{CO}_{2}$ in the fruit with Lifespan treatments than the rest of the bags.

Sulfur dioxide measured in table grapes cv. Thompson seedless showed significant differences $(\mathrm{P} \leq 0.000)$ between treatments after $50 \mathrm{~d}$ of storage (Figure 7).

As shown in Figure 7, the treatment with the lower levels of $\mathrm{SO}_{2}$ was the treatment with Lifespan bag + Bottom $\left(\mathrm{T}_{6}\right)$, which showed no significant differences with Packaging Generic treatment $\left(\mathrm{T}_{0}\right)$, with the treatment of perforated bags with copper nanoparticles + Bottom $\left(\mathrm{T}_{8}\right)$ and with the

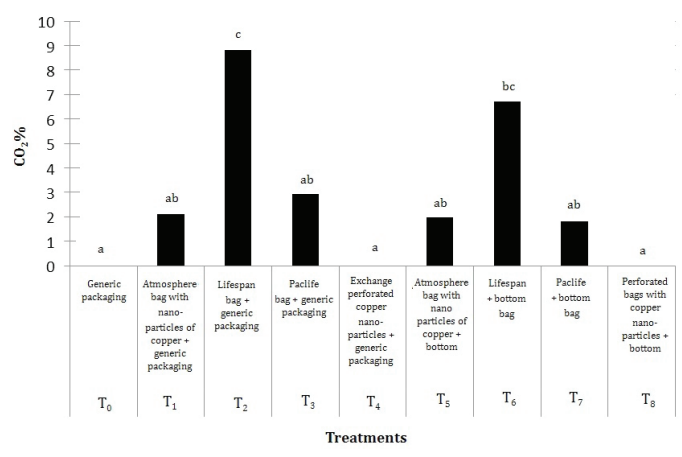

Figure 6. Comparison of average of $\mathrm{CO}_{2}$ levels between treatments measured after $50 \mathrm{~d}$ of storage. Different letters indicate statistically significant differences.

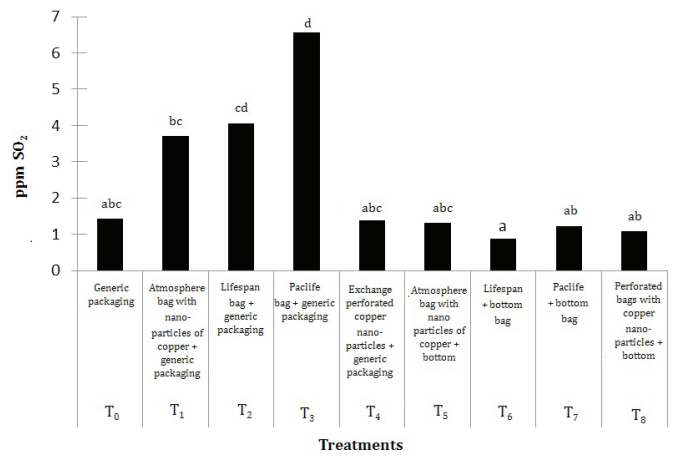

Figure 7. Comparison of the average of $\mathrm{SO}_{2}$ levels (ppm) between treatments measured after $50 \mathrm{~d}$ of storage. Different letters indicate statistically significant differences.

treatment of perforated bag with copper nanoparticles + generic Packaging $\left(\mathrm{T}_{4}\right)$ because all of these treatments had a perforated bag that allowed for increased ventilation. It also did not differ from the treatments with the atmosphere bag with copper nanoparticles + Bottom and with the Paclife bag + Bottom $\left(\mathrm{T}_{7}\right)$ because these treatments did not have a sulfur dioxide generator.

Moreover, treatments that had the highest levels of $\mathrm{SO}_{2}$ were the atmosphere bag with copper nanoparticles + generic packaging $\left(\mathrm{T}_{1}\right)$, the LifeSpan bag + generic packaging $\left(\mathrm{T}_{2}\right)$ and the Paclife bag + generic packaging $\left(\mathrm{T}_{3}\right)$. The highest levels of $\mathrm{SO}_{2}$, compared to the other treatments, are associated with the use of a bag without ventilation and with the use of a sulfur dioxide generator.

It was observed that none of the attributes of the evaluated fruit showed significant differences between the groups. Flavor was identified by 
panelists as closest to the average between sweet and sour. Furthermore, panelists were unable to perceive and distinguish differences in specific aromas in the berries regardless of the treatment. When analyzing color, panelists identified green tones. When analyzing texture, panelists perceived characteristics between flaccid grapes with crispy ones. When determining acceptability, panelists evaluated grapes with a score of $4=$ "I like something." $\mathrm{CO}_{2}$ concentrations above $20 \%$ may induce oxygenic reactions and physically damage plant tissue in the fresh product, diminishing the quality of post-harvest process. In addition, $\mathrm{O}_{2}$ concentrations below $2.5 \%$ increase the production of carbon dioxide and generate abnormal flavors and odors as a result of the fermentation process at low $\mathrm{O}_{2}$ levels (Ospina and Cartagena, 2008). "The response of panelists to sensory and acceptability attributes measured were not significant because of the levels of $\mathrm{O} 2$ and $\mathrm{CO} 2$ were not obtained for any of these treatments. However; acceptability of fruit was evaluated at a low stringency.

\section{Discussion}

The use of bags with and without copper nanoparticles that modify atmosphere could control post-harvest Botrytis cinerea without the use of a sulfur dioxide generator, maintaining physi- cal and chemical parameters in table grapes cv. Thompson seedless.

The attributes of the fruit quality and conditions evaluated showed significant differences between groups only in the stalk dehydration and bleaching parameters.

Treatments with a sulfur dioxide generator had berries with higher levels of whitening and with lower levels of dehydration than other the grape berries evaluated.

The Lifespan bag treatment $\left(\mathrm{T}_{2}\right.$ and $\left.\mathrm{T}_{6}\right)$ produced $\mathrm{O}_{2}$ and $\mathrm{CO}_{2}$ levels closest to the commercial values.

The highest $\mathrm{SO}_{2}$ levels were achieved in atmosphere bags with and without nanocopper particles in combination with the use of a sulfur dioxide generator.

Treatments that had a higher incidence of rot were those that lacked a sulfur dioxide generator, with the exception of the treatment with Lifespan Bag + Bottom $\left(\mathrm{T}_{6}\right)$, which showed the lowest levels of rot, mainly associated with the levels of $\mathrm{O}_{2}$ and $\mathrm{CO}_{2}$ achieved.

Regarding sensory evaluation to identify and measure acceptability and sensory attributes, no significant differences for any of the treatments were seen.

\section{Resumen}

N.E. Loyola López, M.R. Carrasco Benavides, P. Duarte, y M.A. Arriola Herrera. 2016. Aumentar la vida útil de las uvas de mesa utilizando diferentes materiales de envasado con cobre y nano partículas para cambiar la atmósfera en uvas de mesa post-cosecha (Vitis vinifera) cv . Thompson Seedless. Cien. Inv. Agr. 44(1): 54-63. Una efectiva forma de controlar pudriciones de post cosecha en uva de mesa es el uso de anhídrido sulfuroso $\left(\mathrm{SO}_{2}\right)$; sin embargo, en determinadas condiciones, el uso de $\mathrm{SO}_{2}$ puede causar blanqueamiento de las bayas. Por ello, se plantea que el uso de bolsas con y sin nano partículas de cobre que modifiquen atmósfera, permitirá el control de Botrytis cinérea, además de prescindir del uso de anhídrido sulfuroso en su forma de generador. Se planteó como objetivo de este ensayo; evaluar el uso de bolsas con y sin nano partículas de cobre que modifiquen atmósfera, controlando Botrytis cinerea en post cosecha, y evaluar su efecto en la conservación de parámetros físicos, químicos y atributos sensoriales en uva de mesa. De los resultados se destaca que el uso de 
bolsas atmósfera con y sin nano partículas de cobre que modificaron atmósfera, excluyendo el uso de generadores de anhídrido sulfuroso, fueron capaces de controlar Botrytis cinerea en postcosecha de uva Thompson seedless, además de conservar los parámetros físicos y químicos. Diferencias significativas se obtuvieron en los parámetros; blanqueamiento, deshidratación y en las magulladuras e incidencia de pudriciones. Los panelistas no pudieron distinguir diferencias en los atributos sensoriales, como tampoco mayor aceptabilidad, independiente del tratamiento aplicado.

Palabras claves: Anhídrido sulfuroso $\left(\mathrm{SO}_{2}\right)$, modificación de atmosfera, pudriciones.

\section{References}

Association of Oficial Analytical Chemists. AOAC. 1990. Official Methods of Analysis 932.12 Solid (Soluble) in Fruit Products. Refractometer Method: Official Methods of analysis of the Association of Official Analytical Chemists, 15th ed. Arlington, Virginia. Inc. 1298 pp.

Bravo, J. 2013. Uva de Mesa: Se Ratifica liderazgo exportador mundial de Chile. http://www.odepa. cl/odepaweb/publicaciones/doc/11258.pdf (accessed 14 Apr. 2014).

Calvo, G. 1994. Tecnología del empaque y conservación de la uva de mesa. En: Primeras Jornadas Regionales de Uva de Mesa. Estación Experimental INTA Alto Valle. http://www. biblioteca.org.ar/libros/210219.pdf (accessed 03 Jun. 2014).

CIREN CORFO. 1997. Estudio Agroecológico VI Región Tomo II. Centro de Información de Recursos Naturales. Publicación N¹17. 367 pp.

Crisosto, C. H., E. J. Mitcham., and A. A. Kader. 2013. A. Uva de mesa: Recomendaciones para mantener la calidad postcosecha. http://postharvest.ucdavis.edu/frutasymelones/Uva_de_Mesa (accessed 03 Apr. 2014).

Gil, G. 2012. Fruticultura: Madurez de la fruta y manejo postcosecha: frutas de climas templado y subtropical. $3^{\text {rd }}$ ed. Santiago, Chile. Ediciones UC. 493 pp.

Giraud, E., A. Ivanova, C.S. Gordon, J. Whelan., and M. J. Considine. 2012. Plant Cell Environ. 35:405-417.

Harvey, J.M., and M. Uota. 1978. Table grapes and refrigeration: fumigation with sulphur dioxide.
Internacional Journal of Refrigeration 1:167172.

Kader, A. A., D. Zagory., and E.L. Kerbel. 1989. Modified atmosphere packaging of fruits and vegetables. Crit Rev Food Sci Nutr 28:1-30.

Kader, A. A. 2004. Postharvest Technology of Horticultural Crops. (ed.). University of California Div. of Agriculture and Natural Resources. 3rd ed. $517 \mathrm{pp}$.

Lavanderos, P. 1998. Efecto del envase y presencia de generador de fondo en la condición de postcosecha de la uva de mesa (Vitis vinifera L.) variedad Thompson seedless. Tesis Ing. Agr. Santiago. Universidad Santo Tomás. 86 pp.

Meilgaard, M., G. V. Civille., and B. T. Carr. 1999. Sensory Evaluation Techniques 3rd ed. Editorial CRS Press. New York, EE.UU.

Melendez, P. 1974. Naturaleza, toxicidad y acción de los fungicidas. In: Seminario Regional sobre insecticidas, fungicidas y herbicidas. 12 al 18 de mayo. Managua, D. N. Nicaragua. Dirección Regional para la zona norte Guatemala C. A. p 35-58.

Muñoz, I., and A. Lobato. 2000. Principales cultivares. In: J. Valenzuela, editor, Uva de mesa en Chile. Colección Instituto de investigación agropecuaria, Santiago, Chile. p. 43-60.

Ospina, S., and Cartagena, J. 2008. La atmósfera modificada: una alternativa para la conservación de los alimentos. Revista Lasallista de investigación 5:112-113.

Retamales, J., and B, Difilippi. 2000. Manejo de Postcosecha. In: J. Valenzuela, editor, Uva de mesa en Chile. Colección Instituto de investigación agropecuaria, Santiago, Chile. p 304-309. 
Santibañez, F., and J.M. Uribe. 1993. Atlas Agroclimático de Chile, Región VI, VII y VIII. Santiago Chile. Universidad de Chile, Facultad de Ciencias Agrarias y Forestales. Blanco y Negro. p 24.

Snowdon, A. L. 1990. A colour atlas of post-harvest diseases and disorders of fruits and vegetables.
Vol. 1: General introduction and fruits. Wolfe Scientific. London.

Valenzuela, J., and A, Lobato. 2001. Uva de mesa, In: SOQUIMICH Agenda del Salitre. 11th ed Sociedad Química y Minera de Chile S.A. Santiago, Chile. p. 921-938. 